\title{
International Fungicide Efficacy Trials for the Management of Soybean Rust
}

\author{
M. R. Miles, United States Department of Agriculture-Agricultural Research Service (USDA-ARS), National Soy- \\ bean Research Center, Urbana, IL 61801; C. Levy, Commercial Farmers Union of Zimbabwe, Harare, Zimbabwe; \\ W. Morel, Ministerio de Agricultura y Ganadería, Centro Regional de Investigación Agrícola (CRIA), Capitán Mi- \\ randa, Itapúa, Paraguay; T. Mueller and T. Steinlage, Department of Crop Sciences, University of Illinois, Urbana \\ 61801; N. van Rij, KwaZulu-Natal Department of Agriculture and Environmental Affairs, Cedara, KwaZulu-Natal, \\ South Africa; R. D. Frederick, USDA-ARS, Foreign Disease-Weed Science Research Unit, Ft. Detrick, MD 21702; \\ and G. L. Hartman, USDA-ARS, National Soybean Research Center, Department of Crop Sciences, University of \\ Illinois, Urbana 61801
}

\begin{abstract}
Miles, M. R., Levy, C., Morel, W., Mueller, T., Steinlage, T., van Rij, N., Frederick, R. D., and Hartman, G. L. 2007. International fungicide efficacy trials for the management of soybean rust. Plant Dis. 91:1450-1458.

The efficacy of fungicides in managing soybean rust was evaluated in 12 environments in South America and southern Africa over three growing seasons from 2002 to 2005. There were differences in final soybean rust severity, defoliation, and yield among the treatments at most locations. In locations where soybean rust was not severe, all the fungicides evaluated reduced severity. In locations where soybean rust was severe, applications of triazole and triazole + strobilurin fungicides resulted in lower severity and higher yields compared with other fungicides. The strobilurin fungicides provided the highest yields in many locations; however, severity tended to be higher than that of the triazole fungicides. There also were differences in yield and severity between the trials with two and three applications of several fungicides, with three applications resulting in less severe soybean rust and higher yields. However, the third application of tebuconazole, tetraconazole, and the mixtures containing azoxystrobin and pyraclostrobin was not needed to maintain yield. These fungicides were among the most effective for managing soybean rust and maintaining yield over most locations.
\end{abstract}

The identification of soybean rust, caused by Phakopsora pachyrhizi Syd. \& P. Syd., in Paraguay in 2001 (14) and its subsequent spread to over $95 \%$ of the soybean production in Brazil through the 2004 growing season $(22,23)$ has heightened the awareness of this disease. The rapid spread of $P$. pachyrhizi and its potential to reduce yields makes this among the most destructive foliar diseases of soybean. Yield losses ranging from 20 to $60 \%$ have been reported in Asia, with losses up to $80 \%$ reported from experimental plots in Taiwan

Corresponding author: M. R. Miles

E-mail: mrmiles@uiuc.edu

Trade and manufacturers' names are necessary to report factually on available data; however, the USDA neither guarantees nor warrants the standard of the product, and the use of the name by the USDA implies no approval of the product to the exclusion of others that may also be suitable.

* The $\boldsymbol{e}$-Xtra logo stands for "electronic extra" and indicates that three supplemental figures not included in the print edition appear online.

Accepted for publication 18 June 2007.

doi:10.1094/PDIS-91-11-1450

This article is in the public domain and not copyrightable. It may be freely reprinted with customary crediting of the source. The American Phytopathological Society, 2007.
(7). Yield losses of 40 to $60 \%$ were reported in southern Africa, with reports of $100 \%$ loss in individual fields (2). During the 2003-04 growing season in Brazil, yield losses were estimated at $10 \%$ of the crop, an increase from the 5\% yield loss reported for the previous growing season (23).

Soybean rust was identified for the first time in the United States in November 2004 (17). The commercial soybean cultivars available in the United States are susceptible to soybean rust, and incorporation of resistance into commercial cultivars is several years away (6). Soybean rust could have a major impact on both total soybean production and production costs in the United States.

The management of soybean rust has been primarily with fungicides $(10,15$, 19,20). Early research from Asia indicated that mancozeb was effective in reducing disease severity and providing some yield protection when compared with unprotected plots $(10,19,20)$. Other compounds available at the time were compared with mancozeb and were effective, but results varied by test $(1,19,20)$. Fungicide trials in India (15) and southern Africa (9) identified several triazole compounds that were effective against soybean rust. More recent trials in Africa and South America have identified additional triazoles, tebucona- zole and tetraconazole, as well as several strobilurins and strobilurin + triazole mixtures, including azoxystrobin, pyraclostrobin, and trifloxystrobin + propiconazole, that were effective for managing soybean rust $(3,11-13,22)$.

Recent studies from Zimbabwe and South Africa have found that fungicides were most effective when applied during early flowering through grain fill; applications made before flowering did not increase yields $(3,9,10)$. These studies also showed that a single fungicide application was effective in reducing disease and protecting yield; however, the timing of the application was critical. Delaying fungicide application until after the disease was established resulted in significant yield losses $(3,9,10)$.

There is limited information on the efficacy of fungicides that could be used in the United States. The Zimbabwe experiments were conducted with Punch Xtra (flusilazole plus carbendazim), which has not been available to U.S. producers. Several of the fungicides used in South America have formulations that differ from products available in the United States. The objective of these experiments was to obtain information on fungicide efficacy for products that are or could be available to producers in the United States in order to support management guidelines for soybean rust.

\section{MATERIALS AND METHODS}

Fungicides were evaluated in the soybean production areas of Paraguay, South Africa, and Zimbabwe during the 200203, 2003-04, and 2004-05 growing seasons (Table 1). The fungicides included in the trials differed in each of the three growing seasons (Tables 2, 3, and 4). There also were differences in the treatments evaluated in Paraguay and Zimbabwe within the 2003-04 and 2004-05 growing seasons (Tables 3 and 4). Azoxystrobin + cyproconazole was commercially available in Paraguay but not in Zimbabwe, whereas flusilazole + carbendazim was available in Zimbabwe but not Paraguay. Further differences were inclusion of oxycarboxin and triflumizole in Zimbabwe but not Paraguay and the inclu- 
sion of the azoxystrobin mixtures in Paraguay but not Zimbabwe in the 2003-04 season.

The experimental design was a split plot with four replications at each location. The main effect was fungicide treatment (products and rates) and the subplot treatments were two or three applications of the main effect treatment. The first application of each subplot treatment was between growth stages (GS) R1 and R2, between first and full bloom (4), with subsequent applications made 20 to 24 days apart. During the 2003-04 growing season, there were three treatments with subplots that differed from the two- and threeapplication protocol described above (Table 3). The first of these was azoxystrobin + propiconazole as the main effect with subplot treatments of a single application at $180+108 \mathrm{~g}$ a.i./ha applied at GS R1, compared with three applications at $90+$ $54 \mathrm{~g}$ a.i./ha applied as described for the three-application protocol. The second treatment was a single application of tetraconazole (Domark 230ME) at $100 \mathrm{~g}$ a.i./ha; the subplot treatments were applications at GS R1 or GS R3. The third treatment that differed was trifloxystrobin + propiconazole applied at GS R1 followed by tebuconazole; the subplot treatments were either one or two applications of tebuconazole, and all applications spaced 20 days apart.

Row width and plot lengths varied by location to conform to local planting practices. All locations in Paraguay and South Africa had row widths of $40 \mathrm{~cm}$; in Zimbabwe, row widths were $70 \mathrm{~cm}$ in the Gwebi Variety Testing Center (Gwebi) and $90 \mathrm{~cm}$ at Rattray Arnold Research Station
(RARS). Plot lengths ranged from 6 to 9 $\mathrm{m}$, with the center $5 \mathrm{~m}$ harvested at all locations except those in Paraguay in the 2003-04 growing season, where the center $6 \mathrm{~m}$ were harvested from plots $9 \mathrm{~m}$ in length. All plots were four rows wide, with all four rows treated with fungicide. The center two rows of each plot were used for all evaluations and harvested for yield. There were two to four nontreated rows between plots to act as a buffer between treatments and as spreader rows within the fields. All cultivars were commercially available and local production practices were followed throughout the growing season.

All locations in Paraguay were infested once or twice by placing infected leaves, collected from volunteer soybean plants near each field, in the spreader rows between plots after flowering. The Cedara location in South Africa was infested between the second and third fungicide application, after rust was found in the area. An early-maturing cultivar was planted 14 to 20 days in advance of the experimental cultivar as a border surrounding the test fields in both locations in Zimbabwe to provide additional inoculum.

In Paraguay, fungicides were applied in a single pass with a $\mathrm{CO}_{2}$-pressurized backpack sprayer equipped with a spray wand with 4 TeeJet TJ8002 nozzles (Spraying Systems Co., Wheaton, IL) spaced $40 \mathrm{~cm}$ apart and calibrated to deliver water at 375 liters/ha. In South Africa, fungicides were applied in two passes per plot, with a battery-pressurized backpack sprayer equipped with two Lurmark hollow cone ceramic ATR80 nozzles (Lurmark Limited, Cambridge, UK) spaced $50 \mathrm{~cm}$ apart and calibrated to deliver water at 200 liters/ha. In Zimbabwe, fungicides were applied in four passes per plot, with a backpack sprayer pressurized by hand, fitted with a pressure regulator and a single Lurmark F110/1.6/3 flood-jet nozzle, and calibrated to deliver water at 400 liters/ha. In all locations, the application wands were held with nozzles centered over the plant row at a height of 20 to $30 \mathrm{~cm}$ above the canopy.

Assessments for soybean rust were made before each fungicide application and at 14- to 24-day intervals after the final application; evaluations continued until defoliation in the control plots interfered with assessment. The severity rating from the latest evaluation was used as the final soybean rust severity. On each date of evaluation, severity was rated as a percentage of leaf area covered with uredinia and associated chlorosis within the canopy. These ratings were either a single assessment encompassing the full canopy or were the mean of assessments from the lower, middle, and upper canopy, each taken at five locations within the plot. The single assessment was obtained by visually evaluating severity on fully developed trifoliates from 5 to 10 plants within the plot. When there were three or more dates with soybean rust present, an area under the disease progress curve (AUDPC) was calculated (18). Defoliation was evaluated visually across the entire plot as percent defoliation.

All plots were hand harvested and mechanically threshed, and seed weights and moistures were obtained. Yields were calculated as kilograms per hectare at $13 \%$ moisture. Analysis of variance was performed using JMP statistical software (ver-

Table 1. Country and location of the fungicide efficacy trials within each growing season, with cultivar name, cultivar growth habit and planting date of the field where the experiment was conducted, days after planting to first application (First appl.), first observation of soybean rust (First obsn.), final severity evaluation (Final eval.) and harvest, the mean final soybean rust severity (\%) from untreated control plots, and mean yield (Yield) for each location

\begin{tabular}{|c|c|c|c|c|c|c|c|c|c|c|}
\hline \multirow[b]{2}{*}{$\begin{array}{l}\text { Season, } \\
\text { country }\end{array}$} & \multirow[b]{2}{*}{ Location name } & \multirow[b]{2}{*}{ Cultivar } & \multirow[b]{2}{*}{$\begin{array}{c}\text { Growth } \\
\text { habit }^{\mathrm{a}}\end{array}$} & \multirow[b]{2}{*}{$\begin{array}{l}\text { Planting } \\
\text { date }\end{array}$} & \multicolumn{4}{|c|}{ Days after planting to } & \multirow[b]{2}{*}{$\begin{array}{c}\text { Severity } \\
(\%)^{\mathbf{b}}\end{array}$} & \multirow[b]{2}{*}{$\begin{array}{c}\text { Yield } \\
(\mathrm{kg} / \mathrm{ha})\end{array}$} \\
\hline & & & & & $\begin{array}{l}\text { First } \\
\text { appl. }\end{array}$ & $\begin{array}{l}\text { First } \\
\text { obsn. }\end{array}$ & $\begin{array}{l}\text { Final } \\
\text { eval. }\end{array}$ & Harvest & & \\
\hline \multicolumn{11}{|l|}{$2002-03$} \\
\hline Paraguay & Romero, Pirapo ${ }^{c}$ & Conquista & $\mathrm{D}$ & $11 / 20 / 2002$ & 58 & 58 & 128 & 136 & 27 & 1,616 \\
\hline Paraguay & Sato, Pirapo ${ }^{c}$ & Nidera 9000 & I & $12 / 17 / 2002$ & 73 & 73 & 127 & 145 & 28 & 1,870 \\
\hline Paraguay & Yasu, Pirapo $^{c}$ & Nidera 7636 & $\mathrm{D}$ & $11 / 7 / 2002$ & 63 & 63 & 114 & 142 & 26 & 2,319 \\
\hline \multicolumn{11}{|l|}{$2003-04$} \\
\hline Paraguay & Sato-1, Pirapo ${ }^{c}$ & Nidera 7500 & $\mathrm{D}$ & $2 / 5 / 2004$ & 59 & 59 & 112 & 118 & 15 & 1,130 \\
\hline Paraguay & Sato-2, Pirapo ${ }^{c}$ & Nidera 7500 & $\mathrm{D}$ & $2 / 7 / 2004$ & 59 & 59 & 112 & 116 & 27 & 1,015 \\
\hline Paraguay & 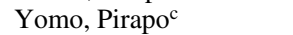 & Mercedes 70 & $\mathrm{D}$ & $11 / 1 / 2003$ & 88 & 88 & 133 & 113 & 6 & 5,656 \\
\hline Zimbabwe & Gwebi $^{\mathrm{d}}$ & Safari & I & $12 / 11 / 2003$ & 50 & 79 & 121 & 143 & 94 & 3,554 \\
\hline Zimbabwe & RARS $^{\mathrm{d}}$ & Storm & $\mathrm{D}$ & $12 / 16 / 2003$ & 50 & 107 & 114 & 128 & 94 & 3,796 \\
\hline \multicolumn{11}{|l|}{ 2004-05 } \\
\hline Paraguay & Krauss, Bella Vista ${ }^{c}$ & Asgrow 8000 & I & $12 / 23 / 2004$ & 55 & 121 & 135 & 151 & 82 & 2,301 \\
\hline South Africa & Cedara, KuaZulu Natal ${ }^{\mathrm{e}}$ & Prima 2000 & I & $11 / 4 / 2004$ & 69 & 93 & 140 & 157 & 80 & 3,565 \\
\hline Zimbabwe & Gwebi $^{\mathrm{d}}$ & Safari & I & $11 / 26 / 2004$ & 50 & 102 & 117 & 146 & 76 & 4,448 \\
\hline Zimbabwe & RARS $^{\mathrm{d}}$ & Storm & $\mathrm{D}$ & $12 / 17 / 2004$ & 50 & 83 & 97 & 133 & 60 & 3,301 \\
\hline
\end{tabular}


sion 5.1; SAS Institute Inc., Cary, NC). Students' least significant difference test was used to compare means, where $\alpha=$ 0.05 . Treatments varied each year and in some cases between countries within a year; therefore, data sets were combined for analysis only when treatments were the same. In the 2004-05 growing season, data from treatments common across locations were used for the cross-location analyses. Because the location-treatment interactions were significant, single location data sets were analyzed for comparison of treatments. Single degree-of-freedom contrasts were used to compare two- and three-application protocol subplots within each treatment using the appropriate error from the analysis of variance.

\section{RESULTS}

2002-03 Growing season. Soybean rust was present prior to the first fungicide application at Romero, Sato, and Yasu in Paraguay during the 2002-03 growing season but the disease development was low, with mean final severities of 26 to $28 \%$ in the nontreated control (Table 1). AUDPC was not calculated for these locations because soybean rust severity did not differ among treatments until the final assessment. Differences were detected between the mean soybean rust severity of the two- and three-application protocols at Romero and Sato but not at Yasu (Table 2). The mean yields at the three locations were low (Table 1) and there were no differences in yield between the application protocols within each location (Table 2).

Final soybean rust severity at all three locations differed among treatments and all fungicide treatments had less disease than the nontreated control (Table 2). Pyraclostrobin and trifloxystrobin + propiconazole were among the treatments that had low soybean rust severity at all three locations, while flutolanil was among the treatments that consistently had high rust severity. Single degree-of-freedom contrasts identified differences between the two and three applications of two and five treatments at Romero and Yasu, respectively, but in nine treatments at Sato. In each comparison, severity was less with three applications compared with two applications of the same fungicide. There were no treatments where differences between application protocols were identified at all three locations, and only pyraclostrobin had low severity with both protocols at all three locations. There were few differences for yield among the fungicide treatments (Table 2). The only treatment to provide yields that differed from that in the nontreated control was boscalid at the Sato location. There also were no differences in yield between the two and three applications within individual treatments. Final disease severity was not correlated with yield at any of the three locations.

2003-04 Growing season. Soybean rust was present prior to the first fungicide application at Sato-1, Sato-2, and Yomo in Paraguay during the 2003-04 growing season; however, the disease development was low, with final severities of 6 to $27 \%$ in the nontreated control (Table 1). In Zimbabwe, soybean rust was first detected 79 and 107 days after planting at Gwebi and RARS, respectively (Table 1). Disease development was high, with a final disease severity of $94 \%$ in the nontreated control at both locations (Table 1). Differences were detected between the mean soybean rust severity and mean yields of the two- and three-application protocols at Gwebi and RARS in Zimbabwe, but not at Sato-1, Sato-2, and Yasu in Paraguay (Table 3).

Table 2. Final soybean rust severity and yield of treatments in the fungicide efficacy trials from three locations in Paraguay during the $2002-03$ growing season

\begin{tabular}{|c|c|c|c|c|c|c|c|c|c|c|}
\hline \multirow[b]{3}{*}{ Active ingredient (product) ${ }^{c}$} & \multirow{3}{*}{$\begin{array}{c}\text { Rate } \\
\text { (g a.i./ha) }\end{array}$} & \multicolumn{6}{|c|}{ Severity $(\%)^{a}$} & \multicolumn{3}{|c|}{ Yield (kg/ha) ${ }^{\mathrm{b}}$} \\
\hline & & \multicolumn{2}{|c|}{ Romero } & \multicolumn{2}{|c|}{ Sato } & \multicolumn{2}{|c|}{ Yasu } & \multirow{2}{*}{$\frac{\text { Romero }}{\text { Mean }}$} & \multirow{2}{*}{$\begin{array}{c}\text { Sato } \\
\text { Mean }\end{array}$} & \multirow{2}{*}{$\begin{array}{c}\text { Yasu } \\
\text { Mean }\end{array}$} \\
\hline & & 2-A & 3-A & 2-A & 3-A & 2-A & 3-A & & & \\
\hline Azoxystrobin (Priori 250EC) ${ }^{\mathrm{d}}$ & 109 & 8 & 9 & 4 & 2 & 14 & $12^{\mathrm{a}}$ & 1,582 & 1,780 & 2,230 \\
\hline Azoxystrobin (Priori 250EC) & 163 & 9 & 8 & 3 & 3 & 6 & 5 & 1,648 & 1,942 & 2,062 \\
\hline Boscalid (Endura 38WG) ${ }^{\mathrm{e}}$ & 224 & 10 & 8 & 2 & 6 & 3 & 3 & 1,651 & 2,071 & 2,254 \\
\hline Chlorothalonil (Bravonil Ultro 82.5\%) & 1,683 & 12 & 9 & 7 & 7 & 17 & $12^{\mathrm{a}}$ & 1,593 & 2,007 & 2,164 \\
\hline Chlorothalonil (Echo 720SC) $)^{\mathrm{f}}$ & 1,440 & 8 & 8 & 2 & 4 & 2 & 1 & 1,480 & 2,021 & 2,255 \\
\hline Fenbuconazole $(\text { Enable } 2 \mathrm{~F})^{\mathrm{g}}$ & 75 & 11 & 10 & 19 & $10^{\mathrm{a}}$ & 1 & 1 & 1,662 & 1,837 & 2,094 \\
\hline Fenbuconazole $(\text { Enable } 2 \mathrm{~F})^{\mathrm{g}}$ & 100 & 11 & 9 & 12 & $6^{\mathrm{a}}$ & 1 & 1 & 1,788 & 1,750 & 2,404 \\
\hline Flutolanil (Moncut 70) & 343 & 18 & $13^{\mathrm{a}}$ & 15 & 12 & 17 & $11^{\mathrm{a}}$ & 1,521 & 1,845 & 2,472 \\
\hline Mancozeb (Dithane 75DF) ${ }^{g}$ & 2,400 & 10 & 10 & 14 & $6^{\mathrm{a}}$ & 14 & $9^{\mathrm{a}}$ & 1,658 & 1,930 & 2,501 \\
\hline Myclobutanil (Laredo 2EC) & 100 & 10 & 10 & 11 & $5^{\mathrm{a}}$ & 1 & 0 & 1,544 & 1,628 & 2,369 \\
\hline Myclobutanil (Systhane 20EW)g & 100 & 13 & 11 & 8 & 4 & 2 & 1 & 1,633 & 1,830 & 2,303 \\
\hline Propiconazole (Propimax 3.6EC) & 120 & 15 & 14 & 16 & $10^{\mathrm{a}}$ & 12 & $7^{\mathrm{a}}$ & 1,605 & 1,785 & 2,251 \\
\hline Propiconazole (Tilt 3.6EC) ${ }^{\mathrm{d}}$ & 126 & 16 & $12^{\mathrm{a}}$ & 13 & $8^{\mathrm{a}}$ & 12 & 13 & 1,612 & 1,817 & 2,316 \\
\hline Pyraclostrobin (Headline 250EC) & 170 & 4 & 4 & 1 & 1 & 2 & 2 & 1,529 & 2,003 & 2,352 \\
\hline Pyraclostrobin + boscalid (Pristine) ${ }^{e, i}$ & $170+168$ & 11 & 11 & 17 & $12^{\mathrm{a}}$ & 14 & 11 & 1,533 & 1,793 & 2,403 \\
\hline Tebuconazole (Folicur 3.6F) $)^{\mathrm{j}}$ & 94 & 12 & 11 & 7 & 4 & 1 & 1 & 1,731 & 1,926 & 2,684 \\
\hline Tetraconazole $(\text { Eminent } 125 \mathrm{SL})^{\mathrm{f}}$ & 100 & 10 & 7 & 17 & $3^{\mathrm{a}}$ & 1 & 0 & 1,456 & 1,756 & 2,409 \\
\hline Trifloxystrobin + propiconazole (Stratego $2.08 \mathrm{EC})^{\mathrm{i}, \mathrm{j}}$ & 128 & 5 & 8 & 3 & 3 & 2 & 1 & 1,717 & 1,911 & 2,189 \\
\hline Undeclared (AMS $21619480 S C)^{j}$ & 100 & 11 & 8 & 9 & $3^{\mathrm{a}}$ & 1 & 1 & 1,742 & 2,028 & 2,215 \\
\hline Nontreated control & $\ldots$ & 29 & 25 & 30 & 25 & 26 & 25 & 1,626 & 1,741 & 2,448 \\
\hline Application protocol mean & $\ldots$ & 12 & $10^{\mathrm{k}}$ & 10 & $7^{\mathrm{k}}$ & 7 & 6 & & & \\
\hline LSD $0.05^{1}$ & $\ldots$ & 3 & 3 & 5 & 5 & 4 & 4 & 295 & 305 & 515 \\
\hline
\end{tabular}

a Significant differences between the means of the two-application (2-A) and three-application (3-A) protocols for each treatment were identified using a single degree of freedom contrast, $P=0.05$, and indicated with an "a" following the late protocol mean. For each treatment, the first application of both protocols was applied after first flower and subsequent applications spaced 20 to 24 days apart.

b The difference between the 2-A and 3-A protocols was not significant, and there were no significant differences between protocols for individual treatments; therefore, data was combined to obtain means for each treatment.

${ }^{\mathrm{c}}$ Active ingredient with product name and formulation.

d Syngenta Crop Protection, Greensboro, NC.

e BASF Ag Products, Research Triangle Park, NC.

${ }^{f}$ Sipcam Agro, Atlanta, GA.

g Dow Agricultural Science, Indianapolis, IN.

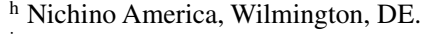

${ }^{\mathrm{i}}$ A nonionic surfactant $(0.125 \%)$ was included in the treatment.

j Bayer Crop Science, Research Triangle Park, NC.

${ }^{\mathrm{k}}$ Difference between means of the application protocols were significant at this location, $P<0.05$.

${ }^{1}$ Students' least significant difference (LSD), where $P<0.05$. 
The final soybean rust severity differed among treatments at all five locations (Table 3). In Sato-1 and Sato-2, all treatments had less severe soybean rust than the nontreated control. At Yomo, where the soybean rust severity was low, all treatments were similar to the nontreated control. There were 16 treatments at Gwebi and 12 at RARS, where severity was less with three applications than with two applications of the same fungicide. Two products, tebuconazole and tetraconazole (Domark 230ME and Eminent 125SL), resulted in severities of $0 \%$ for both the two- and three-application protocols at Gwebi and RARS. When tetraconazole (Domark 230ME) at $100 \mathrm{~g}$ a.i./ha was applied once at GS R1 or GS R3, the soybean rust severity was $0 \%$, as were the two and three applications at 85, 100, and 115 $\mathrm{g}$ a.i./ha. However, at one location, Gwebi, the GS R1 application had a severity of $69 \%$ and was similar to the nontreated control. When a single application of azoxystrobin + propiconazole at $180+108$ $\mathrm{g}$ a.i./ha applied at GS R1 was compared with three applications at $90+54 \mathrm{~g}$ a.i./ha spaced 20 days apart, the disease severity from the single application was similar to that of the nontreated control, whereas the three applications had lower soybean rust severity at both locations. Final rust severity and AUDPC (data not presented) were highly correlated at Gwebi $(r=0.95, P=$ $0.0001)$, RARS $(r=0.95, P=0.0001)$, Sato-1 $(r=0.92, P=0.0001)$, Sato-2 $(r=$ $0.97, P=0.0001)$, and Yomo $(r=0.37, P=$ 0.0001).
Yields differed among treatments at all five locations (Table 3). Mean yields were low at both Sato locations, ranging from 713 to $1,263 \mathrm{~kg} / \mathrm{ha}$, but were high at Yomo, ranging from 4,609 to $6,489 \mathrm{~kg} / \mathrm{ha}$. At Yomo, where disease severity was low, most treatments were similar in yield to the nontreated control; the exceptions included azoxystrobin + propiconazole, myclobutanil at $100 \mathrm{~g}$ a.i./ha, pyraclostrobin, and tetraconazole (Domark 230ME) at 115 $\mathrm{g}$ a.i./ha with three applications. In Gwebi, where disease severity was high, all treatments provided higher yield than the nontreated control except two applications of azoxystrobin + propiconazole, oxycarboxin, and tetraconazole (Domark 230ME) at $115 \mathrm{~g}$ a.i./ha. At RARS, all treatments provided higher yields than the nontreated

Table 3. Final soybean rust severity and yield of treatments in the fungicide efficacy trials in Paraguay and Zimbabwe during the 2003-04 growing season

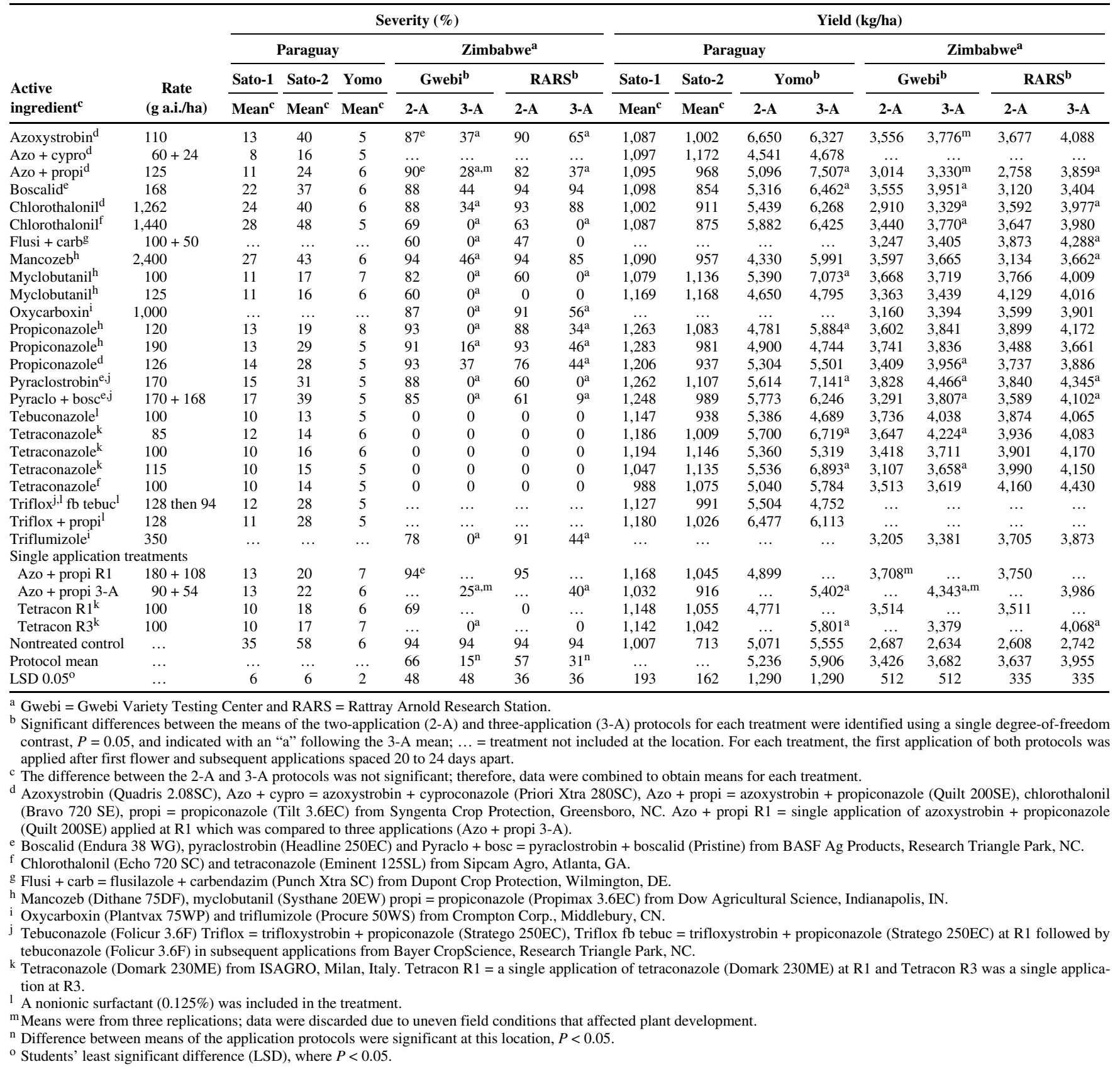


control except for two applications of azoxystrobin + propiconazole. When compared across locations, pyraclostrobin was consistently among the treatments providing the highest yield, whereas boscalid, chlorothalonil (Bravo 720SC and Echo 720SC), mancozeb, oxycarboxin, and triflumizole tended to be among the treatments providing lower yield.

Differences in yield between the twoand three-application protocols were identified in nine, seven, and nine treatments at Gwebi, RARS, and Yomo, respectively; in each comparison, three applications provided higher yields. Pyraclostrobin was the only treatment where a difference in yield between two and three applications was identified at all three locations. At RARS with tebuconazole and tetraconazole (Domark 230ME and Eminent 125SL), the treatments with $0 \%$ disease severity for both two and three applications were among the higher yielding treatments and there were no differences in yield between two and three applications for any treatment of both fungicides. At Gwebi, there were differences in yield between the two and three applications of tetraconazole
(Domark 230ME) at 85 and $115 \mathrm{~g}$ a.i./ha and, in each comparison, three applications provided higher yields.

The single GS R3 application of tetraconazole (Domark 230ME) at $100 \mathrm{~g}$ a.i./ha was similar in yield to the two and three applications at 85, 100, and $115 \mathrm{~g}$ a.i./ha at Gwebi, RARS, and Yomo. However, at one location, Gwebi, the yield provided by three applications at $85 \mathrm{~g}$ a.i./ha was higher. The GS R3 application also provided a higher yield than the single application at GS R1 at RARS and Yomo but not at Gwebi. When a single application of azoxystrobin + propiconazole at $180+108$ $\mathrm{g}$ a.i./ha applied at GS R1 was compared with three applications at $90+54 \mathrm{~g}$ a.i./ha spaced 20 days apart, three applications provided higher yield at Gwebi and Yomo but not at RARS. Both treatments provided higher yield than the nontreated control at Gwebi and Yomo but not at RARS. Final rust severity was inversely correlated with yield at Gwebi $(r=-0.21, P=0.003)$, RARS ( $r=-0.58, P=0.0001)$, and Sato-2 $(r=-0.39, P=0.0001)$ but was not correlated at Sato- 1 and Yomo. The correlations between yield and AUDPC were similar, with an inverse correlation at Gwebi ( $r=$ $-0.30, P=0.003)$, RARS $(r=-0.63, P=$ $0.0001)$, and Sato-2 $(r=-0.34, P=$ $0.0001)$, but the correlations were not significant at Sato-1 and Yomo.

Defoliation was recorded at Sato-1, Sato-2, Gwebi, and Yomo and there were differences among treatments at all four locations. However, no treatment was consistently among those with the lowest defoliation across all locations (data not presented). All treatments differed from the nontreated control in Sato-2 and Yomo. At Yomo, the treatment that resulted in the lowest defoliation was azoxystrobin followed by trifloxystrobin + propiconazole; however, in Sato-2, treatments that resulted in the lowest defoliation included azoxystrobin, myclobutanil, propiconazole, tebuconazole, and tetraconazole (Domark 230ME and Eminent 125SL). In Sato-1, the treatments that resulted in the lowest defoliation included azoxystrobin, pyraclostrobin, and trifloxystrobin + propiconazole, whereas the treatments with boscalid, chlorothalonil, mancozeb, and tetraconazole were similar to the nontreated control. Differences in defolia-

Table 4. Final soybean rust severity and yield of treatments in the fungicide efficacy trails in Paraguay, South Africa, and Zimbabwe during the 2004-05 growing seasons

\begin{tabular}{|c|c|c|c|c|c|c|c|c|c|c|c|c|c|c|c|c|}
\hline \multirow{3}{*}{$\begin{array}{l}\text { Active } \\
\text { ingredient }^{c}\end{array}$} & \multirow{3}{*}{$\begin{array}{c}\text { Rate } \\
\text { (g a.i./ha) }\end{array}$} & \multicolumn{8}{|c|}{ Severity $(\%)^{a}$} & \multicolumn{7}{|c|}{ Yield (kg/ha) } \\
\hline & & \multicolumn{2}{|c|}{ Cedarab $^{b}$} & \multicolumn{2}{|c|}{ Krauss $^{\text {b }}$} & \multicolumn{2}{|c|}{ Gwebi $^{\text {b }}$} & \multicolumn{2}{|c|}{ RARS $^{\mathbf{b}}$} & \multicolumn{2}{|c|}{ Cedara $^{b}$} & \multirow{2}{*}{$\frac{\text { Krauss }^{\mathbf{b}}}{\text { Mean }^{\mathrm{c}}}$} & \multicolumn{2}{|c|}{ Gwebi $^{\text {b }}$} & \multicolumn{2}{|c|}{ RARS $^{\mathbf{b}}$} \\
\hline & & 2-A & 3-A & 2-A & 3-A & 2-A & 3-A & $2-A$ & 3-A & $2-A$ & 3-A & & $2-A$ & 3-A & $2-A$ & 3-A \\
\hline Azo + cypro ${ }^{d}$ & $60+24$ & 61 & 63 & 18 & 4 & $\ldots$ & .. & $\ldots$ & .. & 3,613 & 3,796 & 2,392 & $\ldots$ & $\ldots$ & $\ldots$ & $\ldots$ \\
\hline Azo + propi $^{\text {d }}$ & $125+75$ & 77 & 72 & 58 & $18^{\mathrm{a}}$ & $\begin{array}{l}\cdots \\
\ldots\end{array}$ & $\begin{array}{l}\cdots \\
\cdots\end{array}$ & $\begin{array}{l}\cdots \\
\cdots\end{array}$ & $\begin{array}{l}\cdots \\
\cdots\end{array}$ & 3,713 & 3,755 & 2,375 & $\begin{array}{l}\cdots \\
\cdots\end{array}$ & $\begin{array}{l}\cdots \\
\cdots\end{array}$ & $\begin{array}{l}\cdots \\
\cdots\end{array}$ & $\begin{array}{l}\cdots \\
\cdots\end{array}$ \\
\hline Chlorothalonil $^{\mathrm{e}}$ & 1,440 & 74 & 75 & 80 & $65^{\mathrm{a}}$ & 53 & $37^{\mathrm{a}}$ & 32 & $8^{a}$ & 3,206 & 3,634 & 2,352 & 3,804 & $4,263^{\mathrm{a}}$ & 3,065 & 3,260 \\
\hline Fenarimol ${ }^{\mathrm{f}, \mathrm{g}}$ & 96 & 79 & 76 & 58 & $25^{\mathrm{a}}$ & 26 & $10^{\mathrm{a}}$ & 0 & 0 & 3,276 & 3,525 & 2,351 & 4,173 & 4,199 & 3,157 & 3,082 \\
\hline Flusilazole ${ }^{\mathrm{h}}$ & 90 & 69 & 66 & 58 & $20^{\mathrm{a}}$ & 21 & $0^{\mathrm{a}}$ & 4 & 1 & 3,620 & 3,619 & 2,301 & 4,130 & 4,452 & 3,365 & 3,209 \\
\hline Flusilazole $\mathrm{h}^{\mathrm{h}}$ & 125 & 70 & 66 & 38 & $8^{\mathrm{a}}$ & 10 & 0 & 0 & 0 & 3,171 & $4,023^{\mathrm{a}}$ & 2,234 & 4,509 & 4,861 & 2,984 & $3,345^{\mathrm{a}}$ \\
\hline Flutrifol $^{\mathrm{i}}$ & 63 & 69 & 64 & 5 & 5 & 0 & 0 & 0 & 0 & 3,738 & 3,292 & 2,465 & 4,312 & 4,726 & 3,317 & $3,625^{\mathrm{a}}$ \\
\hline Metconazole $\mathrm{j}^{\mathrm{j}}$ & 54 & 73 & 69 & 35 & $14^{\mathrm{a}}$ & 1 & 0 & 37 & $11^{\mathrm{a}}$ & 3,937 & 3,723 & 2,275 & 4,271 & 4,646 & 3,278 & 3,285 \\
\hline Met + pyraclo & $40+65$ & 69 & 64 & 15 & 3 & 2 & 0 & 4 & 4 & 3,575 & 3,452 & 2,361 & 4,548 & $5,212^{\mathrm{a}}$ & 3,491 & 3,195 \\
\hline Met + pyraclo & $52+65$ & 63 & $\begin{array}{l}04 \\
56\end{array}$ & 15 & 4 & 1 & 0 & 29 & $1^{\mathrm{a}}$ & 3,633 & 4,027 & 2,190 & $\begin{array}{l}4,540 \\
4,454\end{array}$ & 4,732 & 3,232 & $3,598^{\mathrm{a}}$ \\
\hline Met + pyracloj & $54+90$ & 65 & $51^{\mathrm{a}}$ & 15 & 1 & 3 & 0 & 12 & $1^{\mathrm{a}}$ & 3,638 & 3,507 & 2,422 & 4,401 & 4,445 & 3,488 & 3,475 \\
\hline Met + pyraclo & $60+75$ & 65 & 60 & 10 & 0 & 5 & 0 & 0 & 0 & 3,540 & $4,027^{\mathrm{a}}$ & 2,420 & 4,437 & 4,570 & 3,695 & 3,561 \\
\hline Oxycarboxin ${ }^{\mathrm{k}}$ & 750 & $\ldots$ & $\ldots$ & $\ldots$ & $\ldots$ & 48 & $24^{\mathrm{a}}$ & 0 & 0 & ... & $\ldots$ & $\ldots$ & 3,745 & $4,221^{\mathrm{a}}$ & 2,888 & 3,125 \\
\hline Propiconazole $^{\mathrm{d}}$ & 189 & $\begin{array}{l}76 \\
76\end{array}$ & $68^{a}$ & 65 & $30^{\mathrm{a}}$ & $\ldots$ & $\ldots$ & $\ldots$ & $\ldots$ & 3,710 & 3,709 & 2,325 & $\ldots$ & $\ldots$ & $\ldots$ & $\ldots$ \\
\hline Propiconazole $^{\mathrm{d}}$ & 125 & 79 & $69^{\mathrm{a}}$ & 55 & $43^{\mathrm{a}}$ & $\begin{array}{l}\cdots \\
\cdots\end{array}$ & $\begin{array}{l}\cdots \\
\cdots\end{array}$ & $\begin{array}{l}\cdots \\
\cdots\end{array}$ & $\begin{array}{l}\cdots \\
\cdots\end{array}$ & 3,250 & 3,181 & 2,247 & $\cdots$ & $\cdots$ & $\cdots$ & $\cdots$ \\
\hline Pyraclostrobing, & 170 & 74 & 67 & 20 & $3^{\mathrm{a}}$ & $\begin{array}{r}\cdots \\
0\end{array}$ & $\begin{array}{l}\cdots \\
0\end{array}$ & $\begin{array}{r}\cdots \\
0\end{array}$ & $\begin{array}{c}\cdots \\
0\end{array}$ & 3,903 & 3,921 & 2,408 & 4,336 & 4,530 & 3,628 & $3,981^{\mathrm{a}}$ \\
\hline Tebuconazole $^{1}$ & 94 & 72 & 69 & 15 & 9 & 0 & 0 & 6 & 0 & 3,983 & 3,959 & 2,301 & 4,203 & 4,609 & 3,218 & 3,089 \\
\hline Tebuconazole ${ }^{1}$ & 100 & 67 & 67 & 8 & 4 & 0 & 0 & 4 & 0 & 3,680 & 3,250 & 2,431 & 4,379 & 4,417 & 3,227 & 3,400 \\
\hline Tebuconazole $^{\mathrm{e}}$ & 125 & 70 & 65 & 3 & 4 & 0 & 0 & 0 & 0 & 3,975 & 3,541 & 2,284 & 4,404 & 4,768 & 3,131 & 3,131 \\
\hline Tetraconazole $^{\mathrm{m}}$ & 85 & 69 & 68 & 4 & 3 & 0 & 0 & 0 & 0 & 3,587 & 3,640 & 2,370 & 4,456 & 4,533 & 3,260 & 3,075 \\
\hline Triflox + propi ${ }^{\mathrm{g}, \mathrm{l}}$ & 182 & 70 & 65 & 30 & $15^{\mathrm{a}}$ & 13 & 0 & 7 & 0 & 2,855 & $4,283^{\mathrm{a}}$ & 2,341 & 4,359 & 4,455 & 3,024 & $3,367^{\mathrm{a}}$ \\
\hline Triflox + propi ${ }^{\mathrm{g}, \mathrm{l}}$ & 146 & 76 & $65^{\mathrm{a}}$ & 43 & $18^{\mathrm{a}}$ & 5 & 0 & 24 & $10^{\mathrm{a}}$ & 3,222 & 3,317 & 2,271 & 4,538 & 4,781 & 3,348 & 3,343 \\
\hline Triflumizole ${ }^{\mathrm{i}}$ & 350 & $\ldots$ & $\ldots$ & $\ldots$ & $\ldots$ & 37 & $22^{\mathrm{a}}$ & 22 & $4^{\mathrm{a}}$ & $\ldots$ & $\ldots$ & $\ldots$ & 4,141 & 4,340 & 3,104 & 3,003 \\
\hline Nontreated control & $\ldots$ & $\begin{array}{l}\cdots \\
80\end{array}$ & $\begin{array}{l}\cdots \\
80\end{array}$ & $\begin{array}{l}\cdots \\
73\end{array}$ & 35 & 77 & 75 & 55 & 64 & 2,597 & 2,582 & 1,713 & 4,130 & 4,088 & 2,981 & 2,910 \\
\hline Protocol mean & $\begin{array}{l}\cdots \\
\cdots\end{array}$ & 71 & $66^{\mathrm{n}}$ & 29 & $16^{\mathrm{n}}$ & 12 & $7^{\mathrm{n}}$ & 12 & $5^{\mathrm{n}}$ & 3,580 & 3,550 & $\begin{array}{c}1,115 \\
\ldots\end{array}$ & 4,325 & $\begin{array}{l}4,000 \\
4,572^{n}\end{array}$ & $\begin{array}{l}2,701 \\
3,272\end{array}$ & 3,330 \\
\hline LSD $0.05^{\circ}$ & $\cdots$ & 8 & 8 & 21 & 21 & 14 & 14 & 16 & 16 & 625 & 625 & 279 & 426 & 426 & 375 & 375 \\
\hline
\end{tabular}

${ }^{\text {a }}$ Significant differences between the means of the two-application (2-A) and three-application (3-A) protocols for each treatment were identified using a single degree-of-freedom contrast, $P=0.05$, and indicated with an "a" following the 3 -A mean; $\ldots=$ treatment not included at the location. For each treatment, the first application of both protocols was applied after first flower and subsequent applications spaced 20 to 24 days apart.

${ }^{\mathrm{b}}$ Cedara $=$ Cedara, South Africa, Krauss $=$ Krauss, Prarguay, Gwebi $=$ Gwebi Variety Testing Center, Zimbabwe and RARS $=$ Rattray Arnold Research Station, Zimbabwe.

c The difference between the 2-A and 3-A protocols was not significant; therefore, data were combined to obtain means for each treatment.

d Azo + cypro = Azoxystrobin + cyproconazole (Priori Xtra 280SC), Azo + propi = azoxystrobin + propiconazole (Quilt 200SE), chlorothalonil $($ Bravo 720 SE), propi = propiconazole (Tilt 3.6EC) from Syngenta Crop Protection, Greensboro, NC.

e Chlorothalonil (Echo 720 SC) and tebuconazole (SA 120 210EC) from Sipcam Agro, Atlanta, GA.

f Fenarimol (Rubigan EC) from Gowan Co., Yuma, AZ.

g A nonionic surfactant $(0.125 \%)$ was included in the treatment.

${ }^{\mathrm{h}}$ Flusilazole (Punch 40EC) from Dupont Crop Protection, Wilmington, DE.

${ }^{\mathrm{i}}$ Flutrifol (Impact 125SC) from Cheminova, Wayne, NJ.

j Metconazole (Carumba 90SL), pyralcostrobin (Headline 250EC) and Met + pyraclo= metconazole + pyraclostrobin from BASF Ag Products, Research Triangle Park, NC

${ }^{\mathrm{k}}$ Oxycarboxin (Plantvax 75WP) and triflumizole (Procure 50WS) from Crompton Corp., Middlebury, CN.

1 Tebuconazole (Folicur 3.6F), Triflox + propi = trifloxystrobin + propiconazole (Stratego 250EC), from Bayer CropScience, Research Triangle Park, NC

${ }^{\mathrm{m}}$ Tetraconazole (Domark 230ME) from ISAGRO, Milan, Italy.

${ }^{\mathrm{n}}$ Difference between means of the application protocols were significant at this location, $P<0.05$.

${ }^{\circ}$ Students' least significant difference (LSD), where $P<0.05$. 
tion between two and three applications were detected with tetraconazole (Eminent 125SL) and myclobutanil, where three applications resulted in lower defoliation than two applications, 85 versus 98 and 86 versus $94 \%$, respectively. In Gwebi, three applications of all products, except boscalid, resulted in less defoliation than the nontreated control (Fig. 1), and there were 12 treatments where defoliation was greater with two applications compared with three applications of the same treatment. Flusilazole + carbendazim, tebuconazole, and tetraconazole were among the treatments that provided the lowest defoliation in both application protocols. The single application of azoxystrobin + propiconazole applied at GS R1 and the three applications at $90+54 \mathrm{~g}$ a.i./ha were similar to the nontreated control, with 92 and $82 \%$ defoliation, respectively. The single applications of tetraconazole (Domark 230ME) at $100 \mathrm{~g}$ a.i./ha applied at either GS R1 or GS R3 differed with 80 and $68 \%$ defoliation, respectively. The defoliation observed with the single GS R3 application was similar to that observed with two or three applications of tetraconazole at 85,100 , or $115 \mathrm{~g}$ a.i./ha. Final rust severity was correlated with defoliation at Gwebi $(r=0.55, P=0.0001)$, Sato-1 $(r=0.31, P=0.0001)$, and Sato-2 $(r=$ $0.67, P=0.0001$ ) but not at Yomo. Correlations between AUDPC and defoliation were similar at each location. The inverse correlation between yield and defoliation was low at Gwebi $(r=-0.19, P=0.0007)$, Sato-1 $(r=-0.33, P=0.0001)$, Sato-2 $(r=$ $-0.44, P=0.0001)$, and Yomo $(r=-0.15$, $P=0.0001)$.

2004-05 Growing season. Soybean rust first was observed between the second and third fungicide applications at Cedara and RARS, but not until after the third application at Gwebi and Kraus (Table 1). The final soybean rust severity was over $75 \%$ for the nontreated control at all locations except RARS, where it was $60 \%$. However, the lower severity at RARS was due to the short time period, 14 days, between first observation of the disease and recording of final severity. A later severity assessment was taken, but high levels of defoliation did not allow for an accurate evaluation. When combined across treatments within a location, the differences between the means of the two- and threeapplication protocols were detected at all four locations for final soybean rust severity (Table 4), at Gwebi and RARS for defoliation (Fig. 2), and only at Gwebi for yield (Table 4). Soybean rust severity differed among treatments at all four locations (Table 4). The lowest severities were observed with metconazole + pyraclostrobin, flutriafol, and azoxystrobin + cyproconazole, followed by flusilazole, tebuconazole, and tetraconazole (Domark 230ME). Differences were detected between the two- and three-application protocols for 4, 11, 5, and 6 treatments at Cedara, Krauss, Gwebi, and RARS, re- spectively. At Cedara, three applications of metconazole + pyraclostrobin at $54+90 \mathrm{~g}$ a.i./ha, trifloxystrobin + propiconazole at $146 \mathrm{~g}$ a.i./ha, and propiconazole at 125 and $189 \mathrm{~g}$ a.i./ha resulted in lower severities compared with two applications of the same fungicide. At Krauss, lower severities were observed with three applications of metconazole, pyraclostrobin, and flusilazole at both 90 and $125 \mathrm{~g}$ a.i./ha; fenarimol and trifloxystrobin + propiconazole at both 146 and $182 \mathrm{~g}$ a.i./ha; and propiconazole at both 125 and $189 \mathrm{~g}$ a.i./ha. At Gwebi and RARS, for all treatments where two applications resulted in greater than $20 \%$ severity, a third application provided decreased severity. At Gwebi, these included chlorothalonil, fenarimol, flusilazole, oxycarboxin, and triflumizole whereas, at RARS, these were metconazole, metconazole + pyraclostrobin at $52+65$ and $54+$ $90 \mathrm{~g}$ a.i./ha, oxycarboxin, trifloxystrobin + propiconazole, and triflumizole. AUDPC followed a pattern similar to the final disease severity, with all treatments different from the nontreated control (data not presented). Final disease severity and AUDPC (data not presented) were correlated at Cedara $(r=0.61, P=0.0001)$, Gwebi $(r=$ $0.58, P=0.0001)$, and RARS $(r=0.37, P$ $=0.0001)$. AUDPC was not calculated at Krauss because the final disease severity was the only assessment with rust present.

Yields differed among treatments at all four locations (Table 4). At Cedara and Krauss, yields were low and, although all

\section{Gwebi, Zimbabwe in 2003-04 season}
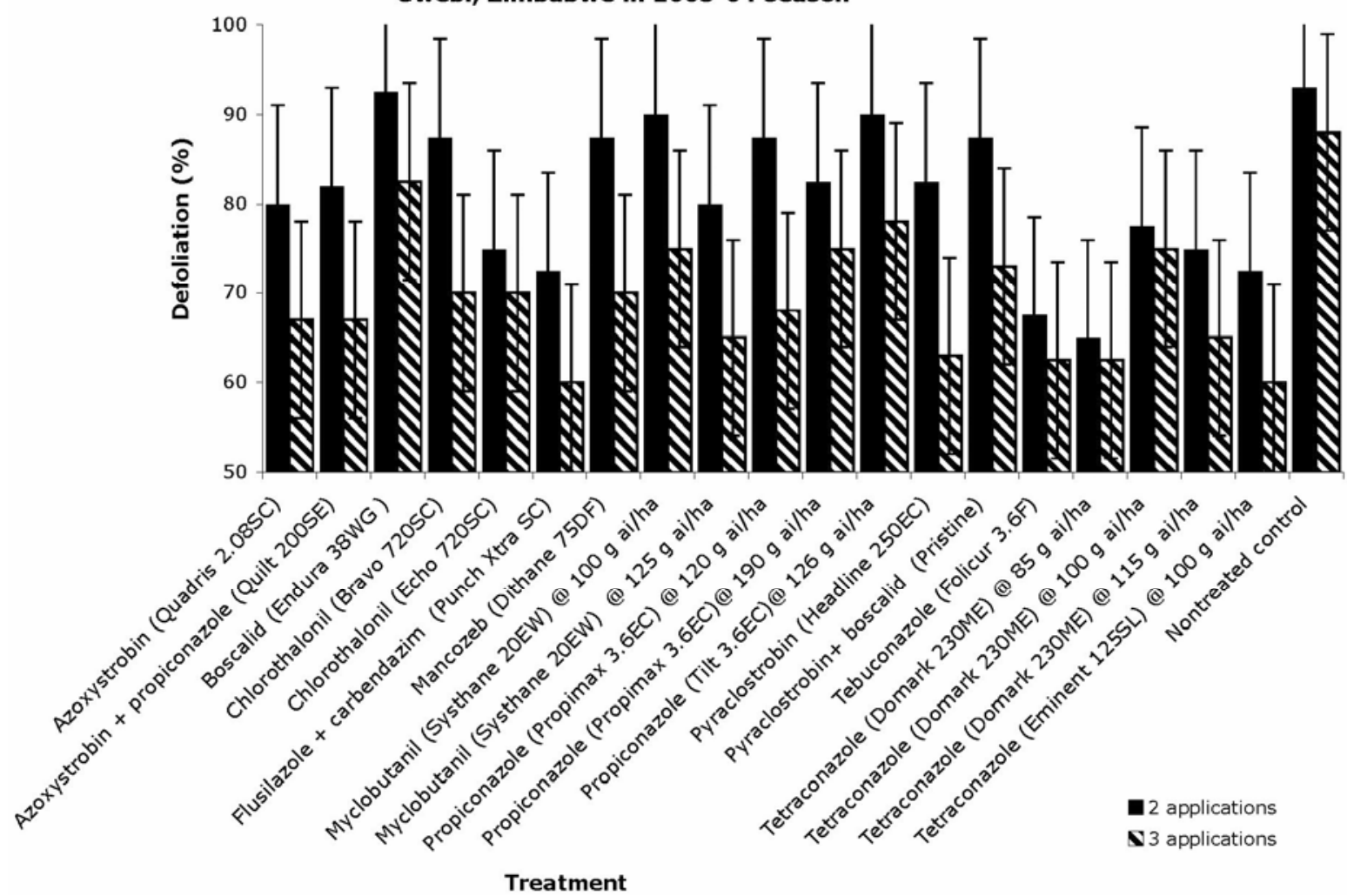

Fig. 1. Percent defoliation observed after two and three applications of each fungicide treatment evaluated in Gwebi, Zimbabwe during the 2003-04 growing season. Means separated by Students' LSD, $P=0.05$, represented by bars. 
treatments provided higher yields than the nontreated control, there was little difference among treatments. At Cedara, the highest yields were those provided by three applications of flusilazole, metconazole + pyraclostrobin at $52+65$ and $60+$ $75 \mathrm{~g}$ a.i./ha, and trifloxystrobin + propiconazole at $182 \mathrm{~g}$ a.i./ha, as well as both the two and three applications of pyraclostrobin and tebuconazole at $94 \mathrm{~g}$ a.i./ha, followed by azoxystrobin + cyproconazole and azoxystrobin + propiconazole. At Krauss, flutriafol provided the highest yield, followed by metconazole + pyraclostrobin at $54+90$ and $60+75 \mathrm{~g}$ a.i./ha, pyraclostrobin, and tebuconazole at $100 \mathrm{~g}$ a.i./ha. Yields were higher in the Zimbabwe locations, but there were several treatments in each location that were similar to the nontreated control, including chlorothalonil, fenarimol, flusilazole, oxycarboxin, tebuconazole at $94 \mathrm{~g}$ a.i./ha, trifloxystrobin + propiconazole, and triflumizole. Flutriafol, metconazole, metconazole + pyraclostrobin, and pyraclostrobin had the highest yields across both locations. Differences in yield between two and three applications were identified in three, three, and five treatments at $\mathrm{Ce}$ dara, Gwebi, and RARS, respectively. At Cedara, the treatments included flusilazole, metconazole + pyraclostrobin at $60+74 \mathrm{~g}$ a.i./ha, and trifloxystrobin + propiconazole at $182 \mathrm{~g}$ a.i./ha. At Gwebi, chlorothalonil, metconazole + pyraclostrobin at $40+65 \mathrm{~g}$ a.i./ha, and oxycarboxin provided higher yields with three applications compared with two applications. At RARS, flutriafol, flusilazole at $125 \mathrm{~g}$ a.i./ha, metconazole + pyraclostrobin at $60+75 \mathrm{~g}$ a.i./ha, pyraclostrobin, and trifloxystrobin + propiconazole at $182 \mathrm{~g}$ a.i./ha provided higher yield with three applications compared with two applications. Final rust severity was inversely correlated with yield at Krauss $(r=-0.28, P=0.0003)$, Gwebi $(r=$ $-0.38, P=0.0001)$, and RARS $(r=-0.27$, $P=0.0006)$ but was not correlated at $\mathrm{Ce}$ dara. Yield and AUDPC also were inversely correlated at Gwebi $(r=-0.37, P=$ $0.0001)$ and RARS $(r=-0.27, P=0.0006)$ but not at Cedara.

The percent defoliation was recorded at Krauss (data not presented), Gwebi, and RARS and there were differences among treatments in all three locations. At both
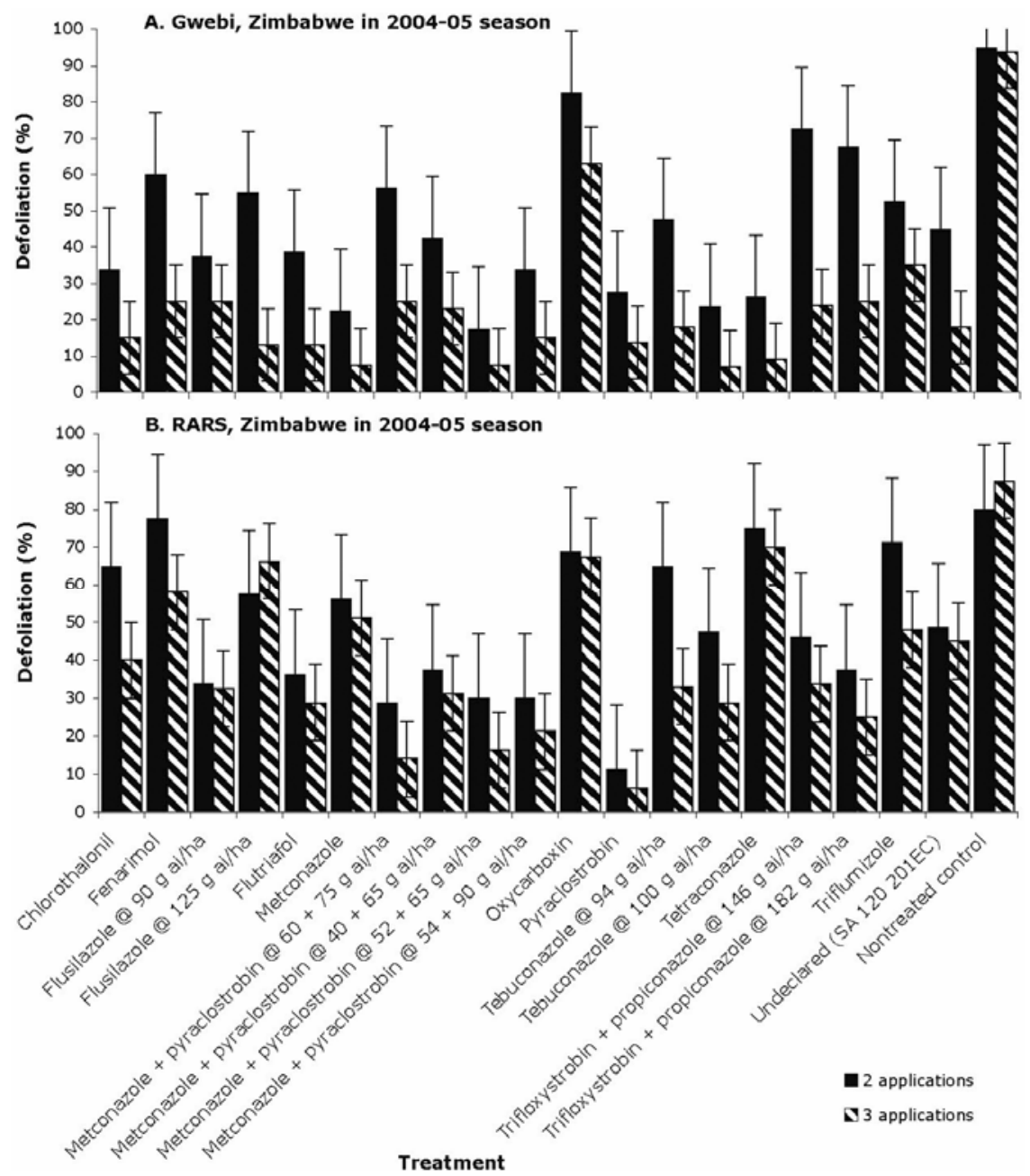

Fig. 2. Percent defoliation observed after two and three applications of each fungicide treatment evaluated in Gwebi and Rattray Arnold Research Station (RARS), Zimbabwe during the 2004-05 growing season. Means separated by Students' LSD, $P=0.05$, represented by bars.

Krauss and Gwebi, defoliation was lower in all treatments compared with the nontreated control; however, at RARS, fenarimol, flusilazole, oxycarboxin, and tetraconazole at $85 \mathrm{~g}$ a.i./ha were similar to the nontreated control. There were no differences in defoliation between two and three applications of the treatments at Krauss, but differences were identified in 15 and 5 treatments at Gwebi and RARS, respectively (Fig. 2). Defoliation was lower with three applications of chlorothalonil, fenarimol, metconazole + pyraclostrobin at $60+75 \mathrm{~g}$ a.i./ha, tebuconazole at $94 \mathrm{~g}$ a.i./ha, and triflumizole compared with two applications in both locations. Pyraclostrobin was among the treatments with the lowest defoliation at both Gwebi and RARS, and defoliation did not differ between two and three applications of the fungicide. Final rust severity was correlated with defoliation at Krauss $(r=0.28$, $P=0.0003)$, Gwebi $(r=0.58, P=0.0001)$, and RARS $(r=0.3, P=0.0001)$. There also was a correlation between AUDPC and defoliation at Gwebi $(r=0.59, P=$ $0.0001)$ and RARS $(r=0.37, P=0.0001)$. Yield and defoliation were inversely correlated at Krauss $(r=-0.28, P=0.0003)$, Gwebi $(r=-0.34, P=0.0001)$, and RARS $(r=-0.46, P=0.0006)$.

\section{DISCUSSION}

In previous studies, chlorothalonil was shown to be as effective as mancozeb for managing soybean rust $(1,15,19,20)$. Chlorothalonil and mancozeb are protectant fungicides which remain on the surface of the leaf and generally are most effective when applied prior to infection. In our studies in the locations where soybean rust severity remained low, the yields provided by the protectant fungicides were higher than that of the nontreated control, even when applied after the disease had been observed in the field. However, in locations where soybean rust severity was high, the protectant fungicides were not among the most effective treatments.

The strobilurin fungicides interfere with spore germination and germ tube development, are absorbed into the leaf tissue, and move in a translaminar manner $(8,16)$. Like chlorothalonil and mancozeb, the strobilurin fungicides are most effective when applied before infection occurs. In Paraguay during the 2002-03 growing season, where soybean rust was observed in the field prior to the first fungicide application and disease severity remained low, the strobilurin fungicides were among the treatments with the lowest severity. During the 2003-04 and 2004-05 growing seasons, where final severity in the nontreated control was over $50 \%$, the strobilurin fungicides were not as consistent, and three fungicide applications were needed to maintain low soybean rust severity. Azoxystrobin, azoxystrobin + propiconazole, and pyraclostrobin tended to be 
among the treatments providing higher yields in locations with severe disease, even when final soybean rust severity recorded for those treatments was high. Further confounding comparisons between treatments are reports that strobilurin fungicides produce a physiological response that may result in increased yields in some environments $(5,8,16)$. In locations with low soybean rust severity, the strobilurin fungicides did not consistently provide yields higher than those provided by the triazole fungicides; therefore, no growth regulatory effect on yield in soybean was inferred. However, the strobilurin fungicides tended to be among the treatments where the lowest defoliation was observed. Delayed senescence is a side effect of strobilurin fungicides reported in other crop species $(5,8,16)$.

The triazole fungicides are sterol inhibitors that interfere with sterol biosynthesis in fungal membranes and are absorbed into the leaf tissue and, like the strobilurins, move in a translaminar manner through the leaf (21). In general, the treatments containing triazole fungicides, alone or in a mixture, performed more consistently than other chemistries. In Zimbabwe, where soybean rust severity was high, low severities were attained with the triazole fungicides flutriafol, metconazole, tetraconazole, and tebuconazole in both the twoand three-application protocols. In locations with high disease severity, the triazole fungicides (tebuconazole and tetraconazole, for example) provided control of soybean rust but were not always among the treatments providing the highest yield. In a previous study, two post-flowering applications of propiconazole were effective in reducing soybean rust and provided yields $33 \%$ greater than the nontreated control (15); in our studies, propiconazole was among the least effective of the triazole fungicides. The treatments with strobilurin-triazole mixtures tended to provide yields similar to or higher than that of the triazole in the mixture. Less severe soybean rust and less defoliation also were observed with the mixture when compared with the triazole alone.

The soybean cultivars in our trials included both determinate and indeterminate growth habits. Although there were no apparent patterns related to the growth habit of the cultivars, the difference between the two growth habits may have contributed to the location-treatment interaction, as well as a difference between the two- and three-application protocols with some treatments. These effects can be seen in Paraguay in 2003, where there were differences detected between two and three applications of nine treatments at the Sato location, but there were differences detected in two and five treatments at Romero and Yasu, respectively. The cultivar planted in Sato had an indeterminate growth habit whereas the cultivars planted in Romero and Yasu had a determinant growth habit.

Correlations between soybean rust severity, defoliation, and yield differed by location. The lowest correlations were in locations with low yield or low severity, or were in locations where yields did not differ among treatments even though there were differences in severity. The highest correlations between disease severity and yield were observed in Zimbabwe during the 2003-04 growing season, where a severe epidemic developed late in the season. At Gwebi, soybean rust first was observed before the plots had reached GS R5; however, at RARS, the first observation was late in GS R5, and the final soybean rust severity in the nontreated control was similar in both locations, 94\%. The nontreated control had $30 \%$ lower yield compared with treatments that provided the highest yield within each location. These results indicate that, if the epidemic is severe and develops rapidly, yield losses can be significant even when soybean rust arrives late in the growing season. Further research is needed to quantify the impact of late-season soybean rust epidemics on yield loss and to determine the stage of maturity at which fungicides are no longer needed for yield protection.

The application protocols, two versus three applications with the first application timed at GS R1, were used as subplot treatments to allow for comparisons of the efficacy of the fungicides without the need to time the fungicide applications to disease onset. These protocols were not developed for commercial soybean production in the United States, but were used to simplify implementation and management of the experiments. There were differences between the two and three applications of several of the fungicides, including boscalid, chlorothalonil, flusilazole + carbendazim, myclobutanil, and propiconazole, where the third application was needed to maintain low severity or provide higher yields. The yield and final disease severity provided by azoxystrobin and pyraclostrobin, alone or in mixtures, also tended to differ between the two- and threeapplication protocols, with three applications resulting in less severe soybean rust and higher yields. However, in many of the locations, the two applications of azoxystrobin and pyraclostrobin were among the treatments providing the highest yields when compared among other twoapplication treatments. Treatments of tebuconazole and tetraconazole were among the treatments that were most consistent, with low disease severity and similar yield provided by both two and three applications.

The differences in yield and disease severity provided by two or three applications of several of the fungicides also support results from previous studies, where the timing of the fungicide applications was critical in managing soybean rust
$(3,9)$. Disease onset was observed after the third fungicide application was made in RARS during the 2003-04 growing season as well as at Krauss and Gwebi in the 2005-06 growing season. Within these locations, three applications of many fungicides were needed to maintain reduced disease severity and provide higher yields. However, two applications of flutriafol, metconazole + pyraclostrobin, myclobutanil, pyraclostrobin, tebuconazole, and tetraconazole maintained low severity and provided yields among the highest in these locations. The effect of application timing was further reinforced by the comparison of the single applications of tetraconazole at GS R1 or GS R3 with two and three applications, all at $100 \mathrm{~g}$ a.i./ha. The single application at GS R3 was similar to two and three applications and was more effective in reducing disease severity and providing higher yield than the application at GS R1. These result indicate that a poorly timed application made too far in advance of disease onset will not provide the protection needed to manage soybean rust. The products that were effective in maintaining disease severity when applied 20 or more days in advance of disease onset were limited to a small set of fungicides, among which tebuconazole and tetraconazole were the most consistent, followed by pyraclostrobin and pyraclostrobin + metconazole. Further research under U.S. production practices will be needed to identify the length of time prior to disease onset that the fungicides approved for use in the United States are effective for management of soybean rust.

The fungicides that were registered and labeled for soybean rust management or included in the Section 18 Emergency Exemption request in the United States were effective against the disease. All fungicides reduced soybean rust and provided higher yields in at least some of the locations. However, the fungicides differed in effectiveness in reducing disease severity and providing higher yield. Among the fungicides that were evaluated in these studies, the mixtures of triazole + strobilurin tended to be most consistent, providing higher yields with less severe soybean rust, lower AUDPC, and less defoliation. The triazole fungicides (tebuconazole and tetraconazole, for example) tended to have low soybean rust severity but did not always provide the highest yields at each location. The strobilurin fungicides (azoxystrobin, pyraclostrobin, and trifloxystrobin) tended to have higher soybean rust severities but provided greater yield with less defoliation. This study provides information to develop guidelines for management of soybean rust using fungicides available in the United States.

\section{ACKNOWLEDGMENTS}

This research was supported by the United Soybean Board as Projects 2229, 3217, and 4217, and 
CSREES Critical Issues Grant 2004-05458 and supports the goals of the USDA National Strategic Plan for the Coordination and Integration of Soybean Rust Research. We thank the field crews in Paraguay, South Africa, and Zimbabwe for managing the fields and conducting the experiments, without whose efforts this work would not have been completed; T. Herman for reviewing the early drafts of the manuscript; and the many companies who supplied products, shipped them to the locations, and funded portions of this research.

\section{LITERATURE CITED}

1. AVDRC. 1992. Annotated bibliography of soybean rust (Phakopsora pachyrhizi Syd.). AVRDC Library Bibliography Series 4-1. G. L. Hartman, E. M Saddoui, and A. T. Tschanz, eds. Tropical Vegetable Information Service, Asian Vegetable Research and Development Center, Taipei, Taiwan.

2. Caldwell, P., and McLaren, N. W. 2004. Soybean rust research in South Africa. Pages 354360 in: Proc. VII World Soybean Res. Conf., IV Int. Soybean Processing and Utilization Conf., III Congresso Mundial de Soja (Brazilian Soybean Conf.). F. Moscardi, C. B. Hoffman-Campo, O. Ferreira Saraiva, P. R. Galerani, F. C. Krzyzanowski, and M. C. CarrãoPanizzi, eds. Embrapa Soybean, Londrina, Brazil.

3. Du Preez, E. D., and Caldwell, P. M. 2004. Chemical control of soybean rust (Phakopsora pachyrhizi) in South Africa. Pages 431-435 in: Proc. VII World Soybean Res. Conf., IV Int. Soybean Processing and Utilization Conf., III Congresso Mundial de Soja (Brazilian Soybean Conf.). F. Moscardi, C. B. HoffmanCampo, O. Ferreira Saraiva, P. R. Galerani, F. C. Krzyzanowski, and M. C. Carrão-Panizzi, eds. Embrapa Soybean, Londrina, Brazil.

4. Fehr, W. R., Caviness, C. E., Burmood, D. T., and Pennington, J. S. 1971. Stage of development descriptions for soybeans, Glycine max (L) Merr. Crop Sci. 11:929-931.

5. Grossmann, K., and Retzlaff, G. 1997. Bioregulatory effects of the fungicidal strobilurin kresoxim-methyl in wheat (Triticum aestivum). Pestic. Sci. 50:11-20.

6. Hartman, G. L., Miles, M. R., and Frederick, R. D. 2005. Breeding for resistance to soybean rust. Plant Dis. 89:664-666.

7. Hartman, G. L., Wang, T. C., and Tschanz, A. T. 1991. Soybean rust development and the quantitative relationship between rust severity and soybean yield. Plant Dis. 75:596-600.

8. Koehle, H., Grossmann, K., Jabs, T., Stierl, R., Gerhard, M., Kaiser, W., Glaab, J., Conrath, U., Seehaus, K., and Herms, S. 2002. Physiological effects of the strobilurin fungicide $\mathrm{F}$ 500 on plants. Pages 61-74 in: Modern Fungicides and Antifungal Compounds, III. H. Lyr, P. E. Russell, H. W. Dehne, and H. D. Sisler, eds. Intercept, Andover, UK.

9. Levy, C. 2004. Zimbabwe-a country report on soybean rust control. Pages 340-348 in: Proc. VII World Soybean Res. Conf., IV Int. Soybean Processing and Utilization Conf., III Congresso Mundial de Soja (Brazilian Soybean Conf.). F. Moscardi, C. B. HoffmanCampo, O. Ferreira Saraiva, P. R. Galerani, F. C. Krzyzanowski, and M. C. Carrão-Panizzi, eds. Embrapa Soybean, Londrina.

10. Miles, M. R., Hartman, G. L., Levy, C., and Morel, W. 2003. Current status of soybean rust control by fungicides. Pestic. Outlook 14:197200.

11. Miles, M. R., Levy, C., and Hartman, G. L. 2004. Summary of the USDA fungicide efficacy trials to control soybean rust in Zimbabwe 2003-2004. USDA National Information System for the Regional IPM Centers. Online publication

12. Miles, M. R., Morel, W., and Hartman, G. L. 2003. Summary of the USDA fungicide efficacy trials to control soybean rust in Paraguay 2002-2003. USDA National Information System for the Regional IPM Centers. Online publication.

13. Miles, M. R., Morel, W., Steinlage, T. A., and Hartman, G. L. 2004. Summary of the USDA fungicide efficacy trials to control soybean rust in Paraguay 2003-2004. USDA National Information System for the Regional IPM Centers. Online publication.

14. Morel, W., Scheid, N., Amarilla, V., and Cubilla, L. E. 2004. Soybean rust in Paraguay, evolution in the past three years. Pages 361364 in: Proc. VII World Soybean Res. Conf., IV Int. Soybean Processing and Utilization Conf., III Congresso Mundial de Soja (Brazil- ian Soybean Conf.). F. Moscardi, C. B. Hoffman-Campo, O. Ferreira Saraiva, P. R. Galer ani, F. C. Krzyzanowski, and M. C. CarrãoPanizzi, eds. Embrapa Soybean, Londrina.

15. Patil, P. V., and Anahosur, K. H. 1998. Control of soybean rust by fungicides. Indian Phytopathol. 51:265-268.

16. Sauter, H., Steglich, W., and Anke, T. 1999 Strobilurins: evolution of a new class of active substances. Angew. Chem. Int. Ed. Engl. 38:1328-1349.

17. Schneider, R. W., Hollier, C. A., Whitman, H. K., Palm, M. E., McKemy, J. M., Hernandez, J. R., Levy, L., and DeVries-Paterson, R. 2005 First report of soybean rust caused by Phakopsora pachyrhizi in the Continental United States. Plant Dis. 89:774.

18. Shaner, G., and Finney, R. E. 1977. The effect of nitrogen fertilization on the expression of slow-mildewing resistance in Knox wheat. Phytopathology 67:1051-1056.

19. Sinclair, J. B. 1977. Control of soybean rust by means other than breeding for resistance. INTSOY Ser. Int. Soybean Program 12:85-88.

20. Sinclair, J. B., and Hartman, G. L. 1995. Management of soybean rust. Pages 6-11 in: Soybean Rust Workshop. J. B. Sinclair and G. L. Hartman, eds. College of Agriculture, Consumer, and Environmental Sciences, National Soybean Research Laboratory Publ. No. 1, Urbana, IL.

21. Tsuda, M., Itoh, H., and Kato, S. 2004. Evaluation of the systemic activity of simeconazole in comparison with that of other DMI fungicides. Pest Manage. Sci. 60:875-880.

22. Yorinori, J. T. 2004. Country report and rust control strategies in Brazil. Pages 447-455 in: Proc. VII World Soybean Res. Conf., IV Int Soybean Processing and Utilization Conf., III Congresso Mundial de Soja (Brazilian Soybean Conf.). F. Moscardi, C. B. HoffmanCampo, O. Ferreira Saraiva, P. R. Galerani, F C. Krzyzanowski, and M. C. Carrão-Panizzi, eds. Embrapa Soybean, Londrina, Brazil.

23. Yorinori, J. T., Paiva, W. M., Frederick, R. D., Costamilan, L. M., Bertagnolli, P. F., Hartman, G. L., and Nunes, J. Jr. 2005. Epidemics of soybean rust (Phakopsora pachyrhizi) in Brazil and Paraguay from 2001 to 2003. Plant Dis. 89:675-677. 